\title{
SARS-CoV-2 Infection Leads to Neurological Dysfunction
}

\section{Arpan Acharya ${ }^{1} \cdot$ Bhavesh D. Kevadiya ${ }^{1,2} \cdot$ Howard E. Gendelman ${ }^{1} \cdot$ Siddappa N. Byrareddy ${ }^{1}$}

Received: 28 April 2020 / Accepted: 6 May 2020 / Published online: 23 May 2020

(C) Springer Science+Business Media, LLC, part of Springer Nature 2020

\begin{abstract}
A number of neurological disease complications have been seen following infection with the severe acute respiratory syndrome coronavirus 2 (SARS-CoV-2). While most person with COVID-19 respiratory disease demonstrate headache, nausea and vomiting, up to $40 \%$ present also experience dizziness, confusion, cerebrovascular disease, muscle pain, ataxia and seizures. Loss of taste and smell, defects in visual acuity and pain occur in parallel. Such central nervous system (CNS) signs and symptoms linked to laboratory-confirmed SARS-CoV-2 infection is often life threatening. Health care providers currently evaluating patients with neurologic symptoms need consider COVID-19 in any differential diagnosis. These considerations will facilitate prompt testing, isolation and prevention of viral transmission speeding best clinical outcomes.
\end{abstract}

Keywords COVID-19 - SARS-CoV-2 · CNS · Neurologic manifestations · Animal models · Guillain-Barré syndrome · Therapeutics

\section{The Coronavirus (CoV)}

CoVs are enveloped positive sense RNA viruses that have four genera: alphacoronavirus, betacoronavirus, gammacoronavirus and deltacoronavirus (Fehr and Perlman 2015). CoV are spherical with a diameter of $125 \mathrm{~nm}$ (Zhao et al. 2012). The viral genome is $30 \mathrm{~kb}$ long with a $5^{\prime}$ cap and $3^{\prime}$ poly-A tail. Up to $20 \mathrm{~kb}$ of the viral genome codes nonstructural proteins, whereas $10 \mathrm{~kb}$ codes for structural proteins. The latter include the viral spike (S), envelop (E), membrane (M) and nucleocapsid (N) (Brian and Baric 2005). The spike proteins project form the envelop surface of the virus giving the virus a solar corona-like appearance, and hence the name corona (Beniac et al. 2006). Spikes are composed of two proteins, termed $\mathrm{S} 1$ and $\mathrm{S} 2$, and these $\mathrm{S} 1 / \mathrm{S} 2$ form

Arpan Acharya and Bhavesh D. Kevadiya contributed equally to this work.

Howard E. Gendelman hegendel@unmc.edu

Siddappa N. Byrareddy sid.byrareddy@unmc.edu

1 Department of Pharmacology and Experimental Neuroscience, University of Nebraska Medical Center, Omaha, NE 68198, USA

2 Interventional Regeneration Medicine and Imaging Laboratory, Department of Radiology, Stanford University, Palo Alto, CA 94304, USA homotrimers that are heavily N-linked glycosylated; specific regions of the S1 protein (termed Receptor Binding Domains, RBD). These engage the ACE2 receptors expressed on cell surface receptors to enter host cells (Delmas and Laude 1990). After binding with the host cell surface receptor, the S1/S2 containing spike is cleaved by a furin-like protease to generate two polypeptides. S1 contains the receptor-binding domain (RDB) and S2 forms the spike protein stalk (Luytjes et al. 1987; Abraham et al. 1990). Human CoV belonging to the betacoronavirus family cause respiratory and enteric diseases and include human CoV 229E, OC43, NL63, HKU1, severe acute respiratory syndrome (SARS) and the Middle East Respiratory Syndrome (MERS). All can lead to pulmonary disease with significant associated morbidities and mortality rates. The present outbreak of the $\mathrm{CoV}$ referenced as SARSCoV-2 was reported from Wuhan, China in late December 2019. Later, on February 11, the World Health Organization (WHO) named the viral strain SARS-CoV-2 and declared its spread a pandemic. The disease that results from SARS-CoV2 infection is called COVID-19 (reviewed recently by Rothan and Byrareddy 2020). SARS-CoV-2 belongs to the clade of SARS-CoVs that include bat-derived viruses (Hu et al. 2017; Luk et al. 2019). Like SARS-CoV, SARS-CoV-2 uses the angiotensin-converting enzyme 2 (ACE-2) receptor to infect host cells that includes, but are not limited to, airway epithelium and parenchyma cells, vascular endothelial cells, kidney and small intestinal cells (Baig et al. 2020). The S1-S2 cleavage site of the spike of SARS-CoV-2 has a unique 12 
nucleotide insertion sequence with three predicted O-linked glycans; whereas most spikes of other HCoV have N-linked glycans (Andersen et al. 2020). The function of the O-linked glycan contains a predicted 'mucin-like domain' with a glycan shield that can promote immune escape (Bagdonaite and Wandall 2018). While awaiting further confirmation, SARSCoV-2 has up to $96 \%$ similarity in genomic sequence with CoVs isolated from horseshoe bats found in caves within the Hunnan China. The bat SARS-CoV is named RaTG13 which was isolated from the Chinese rufous horseshoe bat (Rhinolophus sinicus). All support the idea that the bat is the natural viral reservoir (Zhou et al. 2020).

\section{Clinical Manifestations and Laboratory Diagnosis of SARS-CoV-2 Infection}

SARS CoV-2 infection leads to significant disease now termed COVID-19. Symptoms of COVID-19 include fever, cough, diarrhea, and fatigue progressing to severe respiratory impairments and the acute respiratory distress syndrome (ARDS). A diagnosis of COVID-19 disease is made by molecular-based (real-time reverse transcriptase-polymerase chain reaction) viral nucleic acid detection and is supported by panels of hematological (reduced numbers of CD45+, CD3+, CD4+, CD8+, CD19+ and CD16/56+ cells, abnormal liver and metabolic functions. These are coincident with upper and lower respiratory tract disease sometimes progressing to ARDS (Fu et al. 2020; Pan et al. 2020). However, such signs and symptoms now appear to be simply a part of the constellation of presenting clinical features for COVID-19. Indeed, recent studies affirm that neurologic disease manifestations are a significant part of an already large number of disease manifestations (Asadi-Pooya and Simani 2020). It is known that invasion of the central nervous system (CNS by the human $\mathrm{CoV}(\mathrm{HCoV})$ occurs shortly after infection and through immune escape. The virus enters the CNS and infects neurons creating a range of disease-related consequences (McGavern and Kang 2011; Desforges et al. 2014a). This includes more widespread neurodegeneration (Li et al. 2016b; Desforges et al. 2019; Wu et al. 2020). CNS disease manifestations commonly appears directly after infection, late in the disease course or following recovery (Conde Cardona et al. 2020). These observations are not only seen for SARS-CoV-2 but are mirrored by all betacoronaviruses (Desforges et al. 2019). Such findings were affirmed during the SARS-CoV pandemic of 2002-2003. During this time autopsy examinations demonstrated $\mathrm{HCoV}$ particles in infected human brain tissues. CNS invasion of zoonotic viruses offers no potential evolutionary advantage. This is underscored by the fact that immune viral clearance is limited for neuronal viral infections. Indeed, antiviral cytolytic T cells demonstrate reduced surveillance activities in the brain (Koyuncu et al. 2013). In a recent case study, meningoencephalitis was seen as a major clinical manifestation of COVID-19. Notably this was recorded without respiratory symptoms (Duong et al. 2020). In this report, a person with a history of type- 2 diabetes presented with a lowgrade fever of $100.5^{\circ} \mathrm{F}$, headache, stiff neck, photophobia, seizure without respiratory distress. Anti-epileptic therapy was started for the management of viral meningitis. The clinical progression demonstrated rapid clinical deterioration with disorientation and hallucinations. SARS-CoV-2 detection tests were positive, and she was treated with hydroxychloroquine with improvement in symptoms during a clinical course of 5 days following admission to hospital. In a second case, a young man in his twenties presented total anosmia and ageusia with high suspicion of SARS-CoV-2 infection (Stripp and Sondergaard 2020).

\section{CoV and Animal Models of CNS Infection}

The localization of the virus in brain tissues was studied in mice infected with SARS-CoV34 and MERS-CoV13 (Netland et al. 2008). The brainstem was the target source of viral infection (McCray et al. 2007; Netland et al. 2008; Li et al. 2016a). As cardio-respiratory impairments could reflect brainstem dysfunction it may, in part, be responsible for ARDS as frequently occurs as a cause of COVID19 mortality among SARS-CoV-2 infected patients (Netland et al. 2008; Dube et al. 2018; Li et al. 2020). This reflects findings in other neurotropic CoVs that included mouse hepatitis virus, porcine hemagglutinating encephalitis virus, and feline $\mathrm{CoV}$ (Greig et al. 1962; Arbour et al. 2000; Foley et al. 2003). While HCoV infections are restricted to the upper and lower respiratory systems, it is clear that virus can cross epithelial barriers to reach the periphery and then be transmitted to other organs including the CNS by hematogenous spread (Gu et al. 2005; Nicholls et al. 2006; Desforges et al. 2014a, b). Most of the human CoV strains including 229E, OC43 and SARS productively infect mononuclear phagocytes (MP). It has been suggested that the virus manipulates innate immune responses intrinsic to this cell lineage and subsequently serves as a reservoir for the virus. MP infection of alveolar macrophages can trigger innate immune activation and release of pro-inflammatory secretory factors that may also, in part, by responsible for lung tissue injury and ARDS.

\section{CNS Viral Entry and Neurological Disease Manifestations}

$\mathrm{HCoV}$ enters the CNS from blood and peripheral organs then spreads to the brain (Collins 2002; Nicholls et al. 2006; Desforges et al. 2007). $\mathrm{HCoV}$ may also enter CNS through 
neuronal dissemination, in which the virus initially infects peripheral neurons and from there, using host cell machinery, infects CNS neurons (Koyuncu et al. 2013) (Fig. 1). Using the murine model of $\mathrm{HCoV}$ infection, it was shown that SARS and $\mathrm{OC} 43$ were able to enter the olfactory bulb after exposure by the nasal route; then using olfactory pathways invades the CNS then specifically the brain stem (Netland et al. 2008; Dube et al. 2018). The fact that COVID-19 patients have
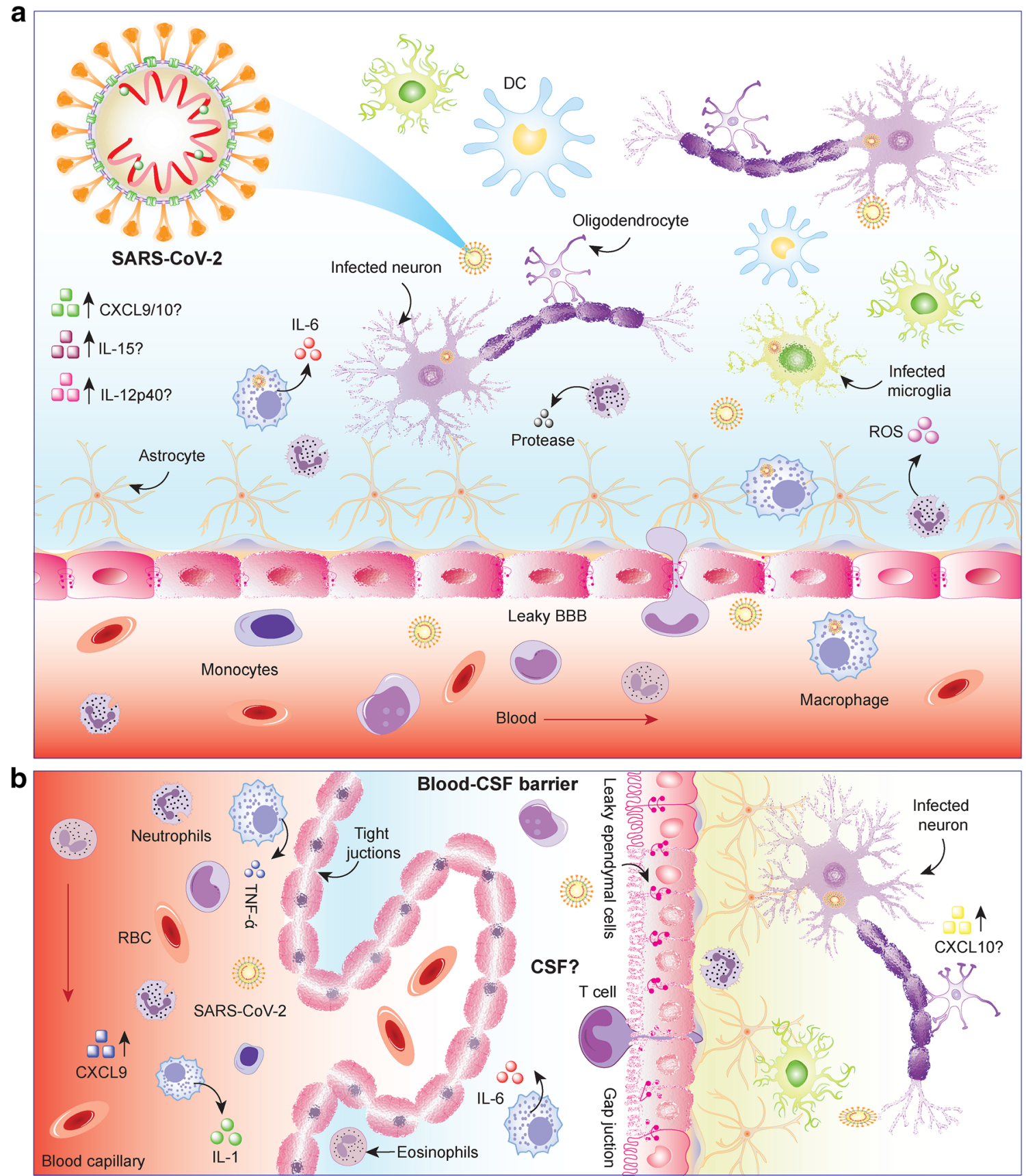

Fig. 1 The neurovirulence of SARS-CoV-2. Increasing data has now provided evidence that SARS-C0V-2 is both neurotropic and neurovirulent. The virus invades the CNS soon after infection and gains access into the CSF and to brain subregions that include the brain stem and cortex. After crossing the blood-brain barrier (BBB) virus can replicate in microglia and neurons with collateral damage to the barrier. An inflammatory cascade is set into motion that includes ongoing collateral damage and secondary seizures, delirium and stroke. A key finding that is the requirements of the ACE2 cell entry receptor. The CoV spike glycoprotein, by which SARS-CoV-2 binds to cell membranes. The expression of this receptor in neurons and endothelial cells outlines the virus neuroinvasive potential. It is possible that both respiratory and neural failures are linked to brain stem damage and as such both direct infection and indirect inflammatory mechanisms are likely both operative. Differential host immune-mediated responses may determine outcomes. Disease models are surely needed to investigate potential neurological complications and to explore mechanisms of alternative immunemediated pathogenicity and developmental therapies 
impaired olfactory function supports this view (Eliezer et al. 2020). Furthermore, the CT scan and MRI analysis of this patient revealed 'bilateral inflammatory obstruction of the olfactory clefts' (Eliezer et al. 2020). SARS-CoV-2 may also play a role in impaired olfactory function due to its structural and genomic similarities to SARS-CoV, as well as its shared mechanism of entrance into host cells by use of the ACE-2 receptor. Xydakis et al., reported anosmia alone or in combination of parageusia is frequently encountered in COVID-19 patients (Xydakis et al. 2020). "The American Academy of Otolaryngology — Head and Neck Surgery" and "The British Association of Otorhinolaryngology" recommends adding these symptoms in the list of primary screening for COVID19 (Xydakis et al. 2020). As the impaired ability to smell and test are a common manifestation of respiratory neurotropic viral invasion of the olfactory system, we suspect there is a possibility that SARS-CoV-2 can infect the olfactory system and may enter the CNS using the olfactory pathway. A retrospective study substantiates this, wherein, $36.4 \%$ of patients out of 214 confirmed cases of SARS-CoV-2 have been documented to present with varying degree of neurological manifestations that include skeletal muscle injury, delirium and acute cerebrovascular disease (Mao et al. 2020) (Fig. 2). Another study from China during the early days of the pandemic, reported neurological manifestations including confusion and headache (Chen et al. 2020b). This report supports results of the previous studies that showed the presence of high titers of $\mathrm{HCoV}$ antibodies found in the cerebrospinal fluid of multiple sclerosis (MS) patients as compared with controls, although both groups had similar levels of serum antibody (Salmi et al. 1982). This is further supported by the finding of the presence of $\mathrm{HCoV}$ RNA in post-mortem brain tissues from MS patients (Stewart et al. 1992). The findings suggest that MS patients are at higher risk of $\mathrm{HCoV}$ neuroinvasion.

It is of interest to examine the data on studies performed using the mouse hepatitis virus (MHV), an enveloped RNA virus that belongs to the coronaviridae family. The MHV produces acute infection of the CNS that gradually gets controlled by cytolytic CD8+ T cells. However, MHV has the capacity to immune escape leading to the establishment of a chronic CNS infection and progressive demyelination in the brain, which is a hallmark of MS (Wu et al. 2000; Bergmann et al. 2006). As SARS-CoV-2, belongs to same family as MHV, it may also be responsible for demyelination in the brain and lead to conditions similar to that noted in MS patients. It is important to remember that MS patients are treated with corticosteroids. They thus remain in an immune-compromised state and fall
Fig. 2 Neurological signs and symptoms occur as a result of SARS-COV-2 infection. These are in addition to life threatening ARDS. These include, but are not limited to, headache, dizziness, myalgia and fatigue, ARDS (a primary part of the disease complex, brain stem (respiratory and cardiac) impairments, primary cardiac disease, anosmia, an inflammatory encephalitis, delirium and cognitive impairments, stroke, seizures, spinal cord injuries and the Guillain-Barre syndrome. All are associated with SARS-CoV-2 infections

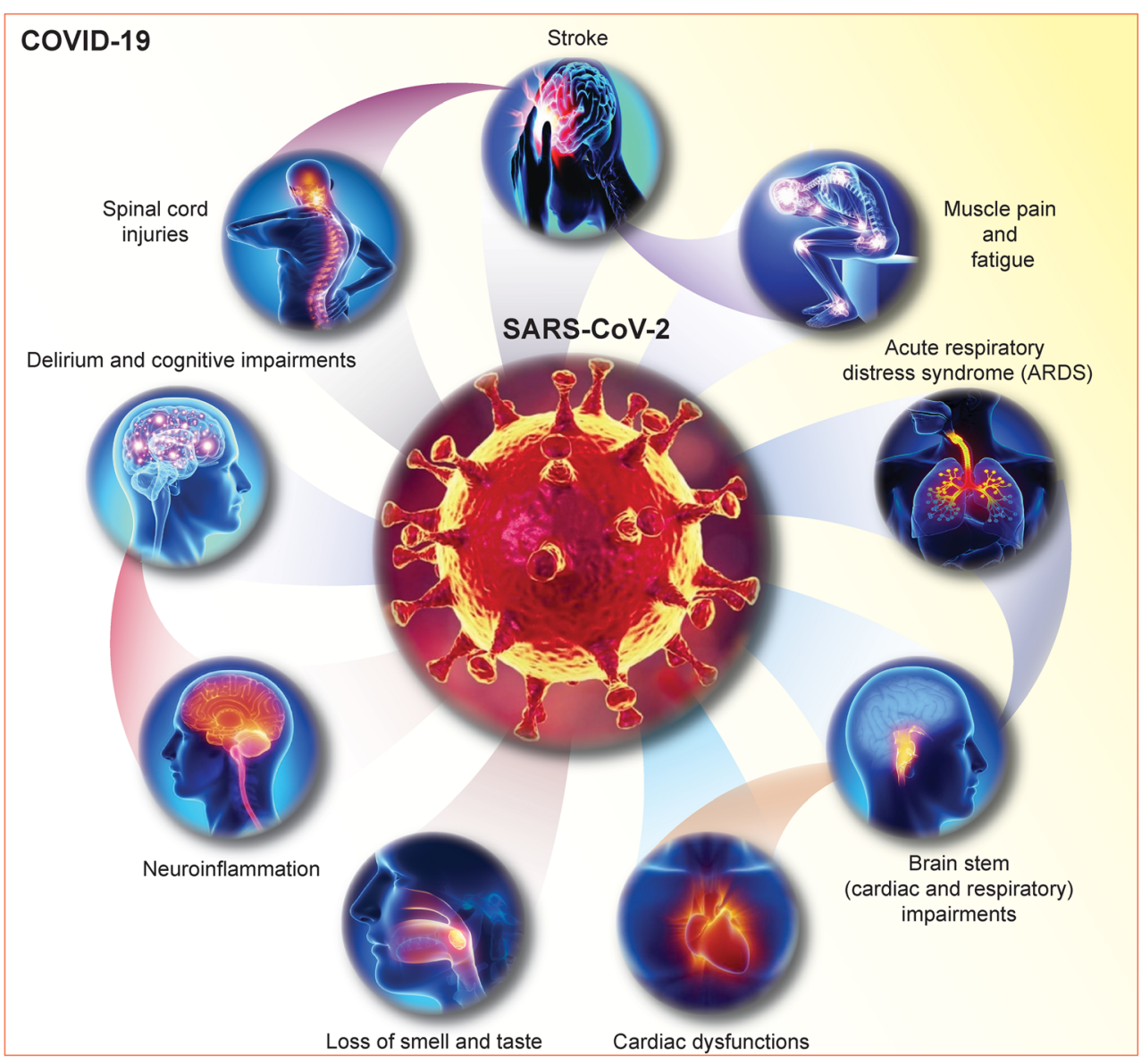


in a high-risk group of getting infected with SARS-CoV-2, which warrants extra careful surveillance of MS patients during this ongoing global pandemic.

\section{Guillain-Barré Syndrome}

Guillain-Barré Syndrome (GBS) is a rare autoimmune disorder that presents with bilateral weaknesses and neuromuscular paralysis (Willison et al. 2016). Among the different phenotypes of GBS "acute inflammatory demyelinating polyradiculoneuropathy" is the most common in which auto-antibodies attack the myelin membranes, whereas in "acute motor axonal neuropathy, autoantibodies attack the axonal membranes of the peripheral nerves (Leonhard et al. 2019). Most of the patients have a history of suffering from a variety of infectious diseases within 4-6 weeks prior to the development of symptoms with GBS. The infectious agents that have so far been reported include Campylobacter jejuni, Mycoplasma pneumoniae, cytomegalovirus, herpes simplex virus, varicella zoster virus, Epstein-Barr virus, hepatitis A virus, hepatitis $\mathrm{B}$ and $\mathrm{E}$, the human immunodeficiency virus (HIV), dengue, chikungunya and ZIKA viruses (Rodriguez et al. 2018). During the ZIKA virus epidemic (2016-2018), several studies reported the development of GBS among ZIKA infected patients, including children. The individuals who developed GBS after ZIKA virus infection had poor prognoses compared to the general population (Araujo et al. 2016; Arias et al. 2017; Barbi et al. 2018; Dirlikov et al. 2018; Major et al. 2018). A recent case report described the potential of SARS-CoV-2 infection which resulted in the detection of reversible GBS (Zhao et al. 2020). A 61-year-old woman with a travel history to Wuhan, China during the 3rd week of January 2020 was first asymptomatic for COVID-19 infection, but developed symptoms of GBS. Subsequently, during follow up treatment, she developed dry cough and fever when SARS-CoV-2 infection was confirmed. The patient was treated with Arbidol and boosted Lopinavir with Ritonavir. With treatment the patient clinical status returned to normal (Zhao et al. 2020). In prior reports, GBS was observed in four patients within a cohort of 23 with confirmed MERS CoV (Kim et al. 2017). Strikingly, the peripheral neurological complications develop after 2 to 3 weeks of recovery from respiratory illness (Kim et al. 2017). Although no direct correlation was established between the development of GBS and COVID-19 for this particular case, the incidence warrants follow up by performing an epidemiological study to monitor development of GBS and or associated neurological disorders among acute/chronic COVID-19 patients as well as in patients who successfully recover from the disease.

\section{Therapeutics for COVID-19 Neurological Manifestations}

The COVID-19 patients, who are above 60 years of age with comorbid conditions that include type 2 diabetes, hypertension, hyperlipidemia and chronic obstructive pulmonary disease may have elevated levels of serum D-dimer, that may lead to embolic vascular events (Chen et al. 2020a; Mao et al. 2020). This includes ischemic stroke necessitating treatment with anti-coagulants (Jin et al. 2020; Khosravani et al. 2020). Hypertensive patients with SARS-CoV-2 infection may have fluctuations in blood pressure that may lead to intracranial hemorrhage. In these patients, to control hypertension, ACE inhibitors should be replaced with calcium channel blockers or diuretics. Cerebrospinal fluid (CSF) should be tested by quantitative polymerase chain reaction tests to detect SARS-CoV-2 in patients with suspected intra-cranial infection. During this COVID-19 pandemic period, all patients coming to the emergency room should be evaluated for symptoms that overlap with neurological manifestations. Individuals suffering from an opioid use disorder are likely at higher risk of developing severe disease. All together the significant neurological disease manifestations now known warrant additional detailed study to explore the diagnostics, disease mechanisms and therapeutic options of COVID-19 disease.

Acknowledgements We thank Michellie Thurman and Robin Taylor for editorial help. The work contained in this study is dedicated to the life and legacy of Ms. Harriet Singer whose philanthropy and dogged spirit enabled this and countless works possible for studies of human brain disease. This work was supported, in part, by R21MH113455, Frances E. Lageschulte and Evelyn B. Weese New Frontiers in Medical Research Fund to SNB and the Carol Swarts, M.D. Emerging Neuroscience Research Laboratory, the Margaret R. Larson Professorship, and the Frances and Louie Blumkin and Harriet Singer Research Foundations. P30MH062261 to HEG and SNB and 1R01AI145542-01A1, P01 DA028555, R01 NS36126, P01 NS31492, 2R01 NS034239, P01 MH64570, P01 NS43985, R01 AG043540, and 1 R56 AI138613-01A1 to HEG.

\section{References}

Abraham S, Kienzle TE, Lapps W, Brian DA (1990) Deduced sequence of the bovine coronavirus spike protein and identification of the internal proteolytic cleavage site. Virology 176:296-301

Andersen KG, Rambaut A, Lipkin WI, Holmes EC, Garry RF (2020) The proximal origin of SARS-CoV-2. Nat Med 26:450-452

Araujo LM, Ferreira ML, Nascimento OJ (2016) Guillain-Barre syndrome associated with the Zika virus outbreak in Brazil. Arq Neuropsiquiatr 74:253-255

Arbour N, Day R, Newcombe J, Talbot PJ (2000) Neuroinvasion by human respiratory coronaviruses. J Virol 74:8913-8921

Arias A, Torres-Tobar L, Hernandez G, Paipilla D, Palacios E, Torres Y, Duran J, Ugarte US, Ardila-Sierra A, Castellanos G (2017) GuillainBarre syndrome in patients with a recent history of Zika in Cucuta, 
Colombia: a descriptive case series of 19 patients from December 2015 to march 2016. J Crit Care 37:19-23

Asadi-Pooya AA, Simani L (2020) Central nervous system manifestations of COVID-19: a systematic review. J Neurol Sci 413:116832

Bagdonaite I, Wandall HH (2018) Global aspects of viral glycosylation. Glycobiology 28:443-467

Baig AM, Khaleeq A, Ali U, Syeda H (2020) Evidence of the COVID-19 virus targeting the CNS: tissue distribution, host-virus interaction, and proposed neurotropic mechanisms. ACS Chem Neurosci 11: 995-998

Barbi L, Coelho AVC, Alencar LCA, Crovella S (2018) Prevalence of Guillain-Barre syndrome among Zika virus infected cases: a systematic review and meta-analysis. Braz J Infect Dis 22:137-141

Beniac DR, Andonov A, Grudeski E, Booth TF (2006) Architecture of the SARS coronavirus prefusion spike. Nat Struct Mol Biol 13:751752

Bergmann CC, Lane TE, Stohlman SA (2006) Coronavirus infection of the central nervous system: host-virus stand-off. Nat Rev Microbiol 4:121-132

Brian DA, Baric RS (2005) Coronavirus genome structure and replication. Curr Top Microbiol Immunol 287:1-30

Chen L, Li Q, Zheng D, Jiang H, Wei Y, Zou L, Feng L, Xiong G, Sun G, Wang H, Zhao Y, Qiao J (2020a) Clinical characteristics of pregnant women with Covid-19 in Wuhan, China. N Engl J Med

Chen N, Zhou M, Dong X, Qu J, Gong F, Han Y, Qiu Y, Wang J, Liu Y, Wei Y, Xia J, Yu T, Zhang X, Zhang L (2020b) Epidemiological and clinical characteristics of 99 cases of 2019 novel coronavirus pneumonia in Wuhan, China: a descriptive study. Lancet 395:507513

Collins AR (2002) In vitro detection of apoptosis in monocytes/ macrophages infected with human coronavirus. Clin Diagn Lab Immunol 9:1392-1395

Conde Cardona G, Quintana Pajaro LD, Quintero Marzola ID, Ramos Villegas Y, Moscote Salazar LR (2020) Neurotropism of SARSCoV 2: mechanisms and manifestations. J Neurol Sci 412:116824

Delmas B, Laude H (1990) Assembly of coronavirus spike protein into trimers and its role in epitope expression. J Virol 64:5367-5375

Desforges M, Miletti TC, Gagnon M, Talbot PJ (2007) Activation of human monocytes after infection by human coronavirus 229E. Virus Res 130:228-240

Desforges M, Le Coupanec A, Brison E, Meessen-Pinard M, Talbot PJ (2014a) Neuroinvasive and neurotropic human respiratory coronaviruses: potential neurovirulent agents in humans. Adv Exp Med Biol 807:75-96

Desforges M, Le Coupanec A, Stodola JK, Meessen-Pinard M, Talbot PJ (2014b) Human coronaviruses: viral and cellular factors involved in neuroinvasiveness and neuropathogenesis. Virus Res 194:145-158

Desforges M, Le Coupanec A, Dubeau P, Bourgouin A, Lajoie L, Dube M, Talbot PJ (2019) Human coronaviruses and other respiratory viruses: underestimated opportunistic pathogens of the central nervous system? Viruses 12(1), pii: E14. https://doi.org/10.3390/ v12010014

Dirlikov E, Major CG, Medina NA, Lugo-Robles R, Matos D, MunozJordan JL, Colon-Sanchez C, Garcia M, Olivero-Segarra M, Malave G, Rodriguez-Vega GM, Thomas DL, Waterman SH, Sejvar JJ, Luciano CA, Sharp TM, Rivera-Garcia B (2018) Clinical features of Guillain-Barre syndrome with vs without Zika virus infection, Puerto Rico, 2016. JAMA Neurol 75:1089-1097

Dube M, Le Coupanec A, Wong AHM, Rini JM, Desforges M, Talbot PJ (2018) Axonal transport enables neuron-to-neuron propagation of human coronavirus OC43. J Virol 92

Duong L, Xu P, Liu A (2020) Meningoencephalitis without respiratory failure in a young female patient with COVID-19 infection in downtown Los Angeles, early April 2020. Brain Behav Immun. pii: S0889-1591(20)30509-2. https://doi.org/10.1016/j.bbi.2020.04.024
Eliezer M, Hautefort C, Hamel AL, Verillaud B, Herman P, Houdart E, Eloit C (2020) Sudden and complete olfactory loss function as a possible symptom of COVID-19. JAMA Otolaryngol Head Neck Surg. https://doi.org/10.1001/jamaoto.2020.0832

Fehr AR, Perlman S (2015) Coronaviruses: an overview of their replication and pathogenesis. Methods Mol Biol 1282:1-23

Foley JE, Rand C, Leutenegger C (2003) Inflammation and changes in cytokine levels in neurological feline infectious peritonitis. J Feline Med Surg 5:313-322

Fu L, Wang B, Yuan T, Chen X, Ao Y, Fitzpatrick T, Li P, Zhou Y, Lin YF, Duan Q, Luo G, Fan S, Lu Y, Feng A, Zhan Y, Liang B, Cai W, Zhang L, Du X, Li L, Shu Y, Zou H (2020) Clinical characteristics of coronavirus disease 2019 (COVID-19) in China: a systematic review and meta-analysis. J Inf Secur. pii: S0163-4453(20)301705. https://doi.org/10.1016/j.jinf.2020.03.041

Greig AS, Mitchell D, Corner AH, Bannister GL, Meads EB, Julian RJ (1962) A Hemagglutinating virus producing encephalomyelitis in baby pigs. Can J Comp Med Vet Sci 26:49-56

Gu J, Gong E, Zhang B, Zheng J, Gao Z, Zhong Y, Zou W, Zhan J, Wang S, Xie Z, Zhuang H, Wu B, Zhong H, Shao H, Fang W, Gao D, Pei F, Li X, He Z, Xu D, Shi X, Anderson VM, Leong ASY (2005) Multiple organ infection and the pathogenesis of SARS. J Exp Med 202:415-424

Hu B, Zeng LP, Yang XL, Ge XY, Zhang W, Li B, Xie JZ, Shen XR, Zhang YZ, Wang N, Luo DS, Zheng XS, Wang MN, Daszak P, Wang LF, Cui J, Shi ZL (2017) Discovery of a rich gene pool of bat SARS-related coronaviruses provides new insights into the origin of SARS coronavirus. PLoS Pathog 13:e1006698

Jin H, Hong C, Chen S, Zhou Y, Wang Y, Mao L, Li Y, He Q, Li M, Su Y, Wang D, Wang L, Hu B (2020) Consensus for prevention and management of coronavirus disease 2019 (COVID-19) for neurologists. Stroke Vasc Neurol. pii: svn-2020-000382. https://doi.org/10. 1136/svn-2020-000382

Khosravani H, Rajendram P, Notario L, Chapman MG, Menon BK (2020) Protected code stroke: Hyperacute stroke management during the coronavirus disease 2019 (COVID-19) pandemic. Stroke: STROKEAHA120029838. https://doi.org/10.1161/STROKEAHA. 120.029838

Kim JE, Heo JH, Kim HO, Song SH, Park SS, Park TH, Ahn JY, Kim MK, Choi JP (2017) Neurological complications during treatment of Middle East respiratory syndrome. J Clin Neurol 13:227-233

Koyuncu OO, Hogue IB, Enquist LW (2013) Virus infections in the nervous system. Cell Host Microbe 13:379-393

Leonhard SE, Mandarakas MR, Gondim FAA, Bateman K, Ferreira MLB, Cornblath DR, van Doorn PA, Dourado ME, Hughes RAC, Islam B, Kusunoki S, Pardo CA, Reisin R, Sejvar JJ, Shahrizaila N, Soares C, Umapathi T, Wang Y, Yiu EM, Willison HJ, Jacobs BC (2019) Diagnosis and management of Guillain-Barre syndrome in ten steps. Nat Rev Neurol 15:671-683

Li K, Wohlford-Lenane C, Perlman S, Zhao J, Jewell AK, Reznikov LR, Gibson-Corley KN, Meyerholz DK, McCray PB Jr (2016a) Middle East respiratory syndrome coronavirus causes multiple organ damage and lethal disease in mice transgenic for human Dipeptidyl peptidase 4. J Infect Dis 213:712-722

Li Y, Li H, Fan R, Wen B, Zhang J, Cao X, Wang C, Song Z, Li S, Li X, Lv X, Qu X, Huang R, Liu W (2016b) Coronavirus infections in the central nervous system and respiratory tract show distinct features in hospitalized children. Intervirology 59:163-169

Li YC, Bai WZ, Hashikawa T (2020) The neuroinvasive potential of SARS-CoV2 may play a role in the respiratory failure of COVID19 patients. J Med Virol. https://doi.org/10.1002/jmv.25728

Luk HKH, Li X, Fung J, Lau SKP, Woo PCY (2019) Molecular epidemiology, evolution and phylogeny of SARS coronavirus. Infect Genet Evol 71:21-30

Luytjes W, Sturman LS, Bredenbeek PJ, Charite J, van der Zeijst BA, Horzinek MC, Spaan WJ (1987) Primary structure of the 
glycoprotein E2 of coronavirus MHV-A59 and identification of the trypsin cleavage site. Virology 161:479-487

Major CG, Dirlikov E, Medina NA, Lugo-Robles R, Matos D, MunozJordan J, Colon-Sanchez C, Garcia-Negron M, Olivero-Segarra M, Malave-Gonzalez G, Thomas DL, Luciano CA, Waterman SH, Sejvar J, Sharp TM, Rivera-Garcia B (2018) Implementation and evaluation of Guillain-Barre syndrome surveillance in Puerto Rico during the 2016 Zika virus epidemic. P R Health Sci J 37:S85-S92

Mao L, Jin H, Wang M, Hu Y, Chen S, He Q, Chang J, Hong C, Zhou Y, Wang D, Miao X, Li Y, Hu B (2020) Neurologic manifestations of hospitalized patients with coronavirus disease 2019 in Wuhan, China. JAMA Neurol. https://doi.org/10.1001/jamaneurol.2020. 1127

McCray PB Jr, Pewe L, Wohlford-Lenane C, Hickey M, Manzel L, Shi L, Netland J, Jia HP, Halabi C, Sigmund CD, Meyerholz DK, Kirby P, Look DC, Perlman S (2007) Lethal infection of K18-hACE2 mice infected with severe acute respiratory syndrome coronavirus. J Virol $81: 813-821$

McGavern DB, Kang SS (2011) Illuminating viral infections in the nervous system. Nat Rev Immunol 11:318-329

Netland J, Meyerholz DK, Moore S, Cassell M, Perlman S (2008) Severe acute respiratory syndrome coronavirus infection causes neuronal death in the absence of encephalitis in mice transgenic for human ACE2. J Virol 82:7264-7275

Nicholls JM, Butany J, Poon LL, Chan KH, Beh SL, Poutanen S, Peiris JS, Wong M (2006) Time course and cellular localization of SARS$\mathrm{CoV}$ nucleoprotein and RNA in lungs from fatal cases of SARS. PLoS Med 3:e27

Pan L, Mu M, Yang P, Sun Y, Wang R, Yan J, Li P, Hu B, Wang J, Hu C, Jin Y, Niu X, Ping R, Du Y, Li T, Xu G, Hu Q, Tu L (2020) Clinical characteristics of COVID-19 patients with digestive symptoms in Hubei, China: a descriptive, cross-sectional, multicenter study. Am J Gastroenterol 115(5):766-773

Rodriguez Y, Rojas M, Pacheco Y, Acosta-Ampudia Y, RamirezSantana C, Monsalve DM, Gershwin ME, Anaya JM (2018) Guillain-Barre syndrome, transverse myelitis and infectious diseases. Cell Mol Immunol 15:547-562

Rothan HA, Byrareddy SN (2020) The epidemiology and pathogenesis of coronavirus disease (COVID-19) outbreak. J Autoimmun 109: 102433
Salmi A, Ziola B, Hovi T, Reunanen M (1982) Antibodies to coronaviruses OC43 and 229E in multiple sclerosis patients. Neurology 32:292-295

Stewart JN, Mounir S, Talbot PJ (1992) Human coronavirus gene expression in the brains of multiple sclerosis patients. Virology 191:502505

Stripp TK, Sondergaard J (2020) [Possible unregistered SARS-CoV-2 infection in a young man with anosmia and ageusia]. Ugeskr Laeger 182(16), pii: V03200189

Willison HJ, Jacobs BC, van Doorn PA (2016) Guillain-Barre syndrome. Lancet 388:717-727

Wu GF, Pewe L, Perlman S (2000) Coronavirus-induced demyelination occurs in the absence of inducible nitric oxide synthase. J Virol 74: 7683-7686

Wu Y, Xu X, Chen Z, Duan J, Hashimoto K, Yang L, Liu C, Yang C (2020) Nervous system involvement after infection with COVID-19 and other coronaviruses. Brain Behav Immun

Xydakis MS, Dehgani-Mobaraki P, Holbrook EH, Geisthoff UW, Bauer C, Hautefort C, Herman P, Manley GT, Lyon DM, Hopkins C (2020) Smell and taste dysfunction in patients with COVID-19. Lancet Infect Dis

Zhao H, Shen D, Zhou H, Liu J, Chen S (2020) Guillain-Barre syndrome associated with SARS-CoV-2 infection: causality or coincidence? Lancet Neurol 19(5):383-384. https://doi.org/10.1016/S14744422(20)30109

Zhao L, Jha BK, Wu A, Elliott R, Ziebuhr J, Gorbalenya AE, Silverman RH, Weiss SR (2012) Antagonism of the interferon-induced OASRNase $\mathrm{L}$ pathway by murine coronavirus ns 2 protein is required for virus replication and liver pathology. Cell Host Microbe 11:607616

Zhou P, Yang XL, Wang XG, Hu B, Zhang L, Zhang W, Si HR, Zhu Y, Li B, Huang CL, Chen HD, Chen J, Luo Y, Guo H, Jiang RD, Liu MQ, Chen Y, Shen XR, Wang X, Zheng XS, Zhao K, Chen QJ, Deng F, Liu LL, Yan B, Zhan FX, Wang YY, Xiao GF, Shi ZL (2020) A pneumonia outbreak associated with a new coronavirus of probable bat origin. Nature 579:270-273

Publisher's Note Springer Nature remains neutral with regard to jurisdictional claims in published maps and institutional affiliations. 